Journal of Universal Language 15-1

March 2014, 79-103

\title{
A Survey of Interjections in International Auxiliary Languages
}

\author{
Alan Reed Libert \\ University of Newcastle, Australia
}

\begin{abstract}
In this paper, I examine various aspects of interjections in international auxiliary languages. Many authors of works on such languages give little or no attention to interjections, apparently thinking that it is not necessary or important to say much about them. The main matter to be discussed is how interjections were created; in some cases they were derived by means of a suffix from words of other classes, in others, zero-derived from other words. In some languages, they are marked in a particular way, distinguishing them from words of other parts of speech. Most works on international auxiliary languages provide very little, if any, information on how interjections are to be used; we will see some instructions which have been given. I will also bring up some of the ideas that language designers have about interjections.
\end{abstract}

Keywords: interjections, auxiliary language, morphology

\footnotetext{
Alan Reed Libert

Department of Linguistics, University of Newcastle, Callaghan, NSW 2308, Australia Phone: 61-2-49215117; Email: Alan.Libert@newcastle.edu.au
}

Received February 15, 2014; Revised March 1, 2014; Accepted March 7, 2014. 
72 A Survey of Interjections in International Auxiliary Languages

\section{Introduction}

Interjections are probably the least discussed part of speech in work on natural languages, and there are those who do not even consider (all of) them to be (completely) linguistic in nature or to be true words. For example, Goffman (1981: 99) states that "exclamatory interjections" such as oops! "are not full-fledged words." Interjections in artificial languages also have received little attention from linguists. ${ }^{1}$ In this paper, I will survey interjections in artificial languages designed to be international auxiliary languages (henceforth IALs). The questions to be examined include what the methods of creation or sources of these words are. It will also be interesting to see different views on interjections held by authors of works on IALs, e.g., whether they belong to language. Therefore, we will look at what language designers and other describers of IALs say about the class of interjections (if they say anything at all). Given that there are more than 1,000 IALs, including those which were not fully developed, it will be impossible to be comprehensive, but this paper will give an idea of trends in the formation of interjections in this type of language, and lines of thought about them.

1 From its title Nate (1996) might appear to be a treatment of interjections in John Wilkins' Real Character and Philosophical Language, but in fact Nate says, "Wilkins' artificial language does not include any interjections at all. Where they are retained in speech, they do not form a part of the artificial language system, and the written character only provides for names which can be given to groups of interjections" (p. 102). I am not certain whether I agree with this, as my interpretation of the relevant pages of Wilkins (1668), namely pp. 388 and 389, is that the symbols he provides for interjections in his "Real Character" might be able to function as interjections (i.e., expressing emotions) in this Character. 


\section{Non-Treatment or Separation of Interjections}

I might first note that some sources on IALs say nothing (significant) about interjections. We should bear in mind that many works on IALs do not present all details of the languages, i.e., many details are left out, and so it would not be surprising if interjections were not brought up in them. However, this is also true, for example, of Giles' (2014) work on Algilez, even though it is 90 pages long.

Gode \& Blair's (1951) book on Interlingua (IALA) has no entry for interjection(s) (or exclamation(s)) in its index, nor among the sections on different word classes is there a section on interjections. There is a section on "Grammatical Words," but interjections are not discussed there, although two words that one might consider interjections are in the list of "minimum list of grammatical words" (ibid.: 51) which is in this section, ecce 'lo!, see!, behold!; here is, here are' and via! 'go away!, begone!.'2 Similarly, neither interjection(s) (nor exclamation $(s)$ ) appears in the index of Butler's (1965) Esperanto textbook, although it generally seems to be rather comprehensive. One could find other examples of the non-treatment of interjections with little difficulty. One of the major secondary sources on artificial languages, Monnerot-Dumaine (1960), does not have a section on interjections, although there are sections on articles, nouns, and so on; to my knowledge, interjections are not mentioned. On the other hand, as we will see, there are IAL designers and describers who discuss interjections at some length.

There are thus many IALs on which I have materials, but about

2 The latter word is given in the entry for the adverb via, which means 'away; off.' There is another form with an exclamation mark in this list, jammais! 'never!,' in the entry for jammais 'ever, at any time.' A shorter work on Interlingua (IALA), Young (2007), has a list of interjections, among which are si 'yes' and no 'no.' 
74 A Survey of Interjections in International Auxiliary Languages

whose interjections I have no significant information (and in some cases the language designer may not have created any interjections). This could be interesting in itself, indicating that interjections might be a low priority for language creators, or it could mean that designers or authors think that nothing need be said about them.

In some other cases, interjections are mentioned but receive very little attention. Some authors give lists of interjections without any comment, including Beermann (1907), Weisbart (1912), de Saussure (1919), and Weferling (1974) in their works on Novilatin, Esperantida, INTAL, and Europal, respectively.

C. L. O'Connor, the designer of American (a modified version of English), brings up interjections a small number of times in his (1917) book on his language, but does not give much information on them, and there are entries for neither $a h$ nor $o h$ in the English-American vocabulary at the end of the book, although this section is 40 pages long. ${ }^{3}$ On page 8 , O'Connor says, "American, of course, has the parts of speech named in English: Nouns, pronouns, adjectives, participles, verbs, adverbs, prepositions, conjunctions, and interjections." On page 16, when stating the categories of inflection of the parts of speech, he says, "Adverbs of manner have degree. Other adverbs and prepositions, and prepositions, conjunctions, interjections, and cardinal numbers are uninflected." He makes a similar statement on page 33: "Prepositions, conjunctions, and interjections do not change their form."

Alfandari (1961: 32), writing about his language Neo, makes little mention of interjections; like O'Connor, he cites them as one of the uninflected parts of speech: "Tous les autres mots (adverbes, prépositions, conjonctions, interjections) sont

3 The American word for 'O' (in at least one function) is $O$, as in one of O'Connor's translations of the two lines at the end of the first verse of "The Star-Spangled Banner': $O$ dic! 'O say!' (p. 45). 
invariables" ("All the other words (adverbs, prepositions, conjunctions, interjections) are invariable.'). ${ }^{4}$

There are also sources that view interjections as being outside of language, or outside of sentences, in some way. For example, in their work on Modern Indo-European, Quiles \& López-Menchero (2012: 152) say, "Interjections are mere exclamations and are not strictly to be classed as parts of speech; as, alā! hello!, $\overline{\mathbf{o}} O$ (vocative), wai alas (grief), ha ha! (laughing sound); ha! (surprise); etc." However, immediately after this sentence, in a "note," they state (ibid.), "Interjections sometimes express an emotion which affects a person or thing mentioned, and so have a grammatical connection like other words." They do not give any examples, and so it is not clear to me what they mean by this.

Similarly, in his extensive grammar of Esperanto, Wennergren (2013: 327) states:

Ekkriaj vortetoj kaj sonimitoj troviĝas iom ekster la ordinara gramatiko. Ili ne interagas kun aliaj vortoj en frazo, sed estas ofte kiel kompleta eldiro en si mem.

('Interjections and onomatopoeias are somewhat outside of ordinary grammar. They do not interact with other words in a sentence, but are often like complete utterances in themselves.')

In their book on Sotos Ochando's Lengua Universal, Gisbert \& Lorrio (1862) write more about interjections than most other authors of works on IALs, and mention the same view:

Muchos hay que no quieren considerar á la interjection

4 The lack of inflection seems to be one of the more mentioned features of interjections in works on IALs; in his book on Hom-idyomo, Cárdenas (1923: I: 145) also brings it up: "The interjection is a non-inflective word used as an exclamation to express an emotion." 
76 A Survey of Interjections in International Auxiliary Languages

como parte de la oracion y que ven en ella una oracion entera que se presenta bajo una forma elíptica. -Así es en efeto la mayor parte de las veces; pero sin embargo, es tambien cierto que todas las lenguas tienen palabras especiales para expresar de un modo sintético y conciso los mas comunes afectos del ánimo, y que sea la que quiera su significacion, aparecen como voces simples; bajo cuyo punto de vista son por lo tanto distintas del nombre, del verbo y de las demás partes del discurso. Sucede además que cada pueblo y aun cada persona, usa especiales palabras para la expresion repentina y elíptica de un afecto, variando segun el tono y modificando caprichosamente la significacion de las voces; todo lo cual está en rigor fuera del dominio de la Gramática de un idoma.

('There are many who do not consider the interjection as a part of speech and who see in it an entire sentence which is presented in an elliptical form. It is indeed such most of the time, but nevertheless it is also certain that all languages have special words to express in a synthetic and concise way the most common emotions of the soul, and that whatever their meaning may be, they appear as simple words; in this point of view they are therefore distinct from the noun, the verb, and the other parts of speech.

It follows further that each people, and even each person, uses special words for the sudden and elliptical expression of an emotion, changing the meaning of the words depending on the tone and modifying it capriciously, all of which is, strictly speaking, outside of the domain of the grammar of a language.')

As we will see below in section 3, in some IALs interjections are clearly part of a systematic scheme of words, or can be 
derived from other words, possibly meaning that they are viewed as part of the language, or of language in general. This may not be the case with Kotava; Fetcey \& le Comite Linguistique Kotava (2013: 8) say the following of interjections, and of "invariable" particles and conjunctions: "Ces catégories sont isolées et n'ont aucun rapport morphologique avec les autres" ("These categories are isolated and do not have any morphological relation with the others.'). It is unclear what this means, perhaps that they are never built from words of other parts of speech. The sentences after it (ibid.) support this:

Les trois premiers niveaux sont appelés expansibles, c'est à dire qu'ils peuvent se développer de façon interne. Par contre, les deux autres sont dits " figés » car ne pouvant être augmentés que de façon externe, par création totale ex nihilo.

('The three first levels 5 are called expandible, that is to say that they can be developed in an internal manner. In contrast, the two others are called "fixed" because they can only be enlarged in an external matter, by creation out of nothing [i.e., from scratch].')

They later (p. 37) state, "Elles [interjections] constituent une classe de mots à part. Ce ne sont ni des substantifs, ni même des adverbes, quoique se rapprochant de ces derniers d'un point de vue syntaxique. Elles sont inclassables et sont bien évidemment invariables" ("They make up a separate word class. 6 They are

5 Earlier on this page there is a table of the parts of speech of Kotava arranged into 5 levels. The first of these contains nouns and verbs, the second "[d]eterminatifs" ('[d]eterminatives'), and the third derived adverbs. Invariable particles, conjunctions, and interjections are on the fifth level.

6 I believe that what is meant by "à part" here is that interjections are separate from or unlike all the other parts of speech (or separate from the rest of language in general). 
neither nouns, nor even adverbs, although they approach these latter from a syntactic point of view. They are unclassifiable and are very obviously invariable').

We have just seen that in Kotava interjections are, one might say, morphology separated from words of other classes, since they apparently cannot be built from them. The reverse seems to be the case for Arulo, i.e., no words of other classes cannot be built from interjections: Talmey (1925: 33) says, "An original interjection cannot furnish a derivative. ${ }^{7}$ This holds particularly true with the interjection yen!, here! look here!" It is uncertain what he means by "original interjection," possibly an underived one. Talmey (ibid.: 18) gives some interjections of Arulo:

(1) adio! 'good-bye,' apage 'away!, begone!,' avante! 'forward!,' bravo! 'bravo!,' fi! 'fie!,' ha!, he!, ho!, ve! 'alas!, wo! [sic],' hola! 'hello!, holla! [sic],' $n u$ 'well,' silencez! 'hush,' yen! 'look here!'

Silencez appears to be morphologically complex, as -ez is the optative/imperative suffix of Arulo; if this is the case, then Arulo does allow interjections to be created out of other types of words, unlike Kotava.

Another way of (mis-)treating interjections is to deny them status as a separate class. Stempfl (1889) seems to do this in his book presenting Myrana, as he lists (p. 70) what seem to be interjections, e.g., $a h$ ! 'ah!' and $o h$ ! 'o(h)!,' in a section on adverbs. Such a view is also expressed by some authors on natural languages, e.g., Kennedy (1879) in his book on Latin, who says, "Interjections are Adverbs hanging loose on the sentence" (p. 228).

In contrast to the apparent views of some authors whom I have mentioned, in his (1856?) book presenting his Philosophic

7 Talmey (ibid.) says that the same is true of conjunctions. 
Language, Edmonds argues at length for the importance of interjections:

Horne Tooke speaks with his usual arrogance respecting Interjections; which almost always express some Characteristic, not assertive. He calls it [sic] "the brutish inarticulate Interjection; which has nothing to do with speech, and is only the miserable refuge of the speechless." And yet, he absurdly says, "it has been permitted, because beautiful and gaudy, to usurp a place among words, \&c." He justifies his bitterness against the Interjection, because, he says, "the dominion of speech is erected on the downfall of Interjections;" . . . He further says, "Voluntary Interjections are only employed when the suddenness or vehemence of some affection or passion returns men to their natural state, and makes them, for a moment, forget the use of speech;" and that, "In books, they are used only for embellishment, and to mark strongly the above situations." But he further says, "where speech can be employed, they are totally useless; and are always insufficient for the purpose of communicating our thoughts." What an absurd and contradictory attack upon this part of speech! . . . He might as well condemn the natural accompaniment of tears and groans, of sighs and sorrowful looks, when narrating some of those facts in which the speaker and the auditor are interested. Those parts of speech which most effectually return us to "a state of nature" are certainly most precious, and indeed, essential to the noblest efforts of oratory and poetry . . . (Introduction, pp. $\left.8-9^{8}\right)$

8 Some different parts of this work have separate page numbering; it is therefore necessary to specify that these are pages 8-9 of the Introduction. I have followed 
80 A Survey of Interjections in International Auxiliary Languages

Notwithstanding Horne Tooke's observations ...., the Interjections are important as parts of discourse; for they are all Subjective, like tears, and groans, and sighs, and smiles, or a serious or vivacious expression of contenance, which naturally and involuntar[il]y indicate, but do not assert, the state of the speaker's feelings and emotions. And if these signs are simulated, as when anyone says, "How beautiful!" or when affecting to be hurt, cries out "Oh," or indicating grief, sheds tears, or sighs, or cries "Alas! Alas!" no one charges him with lying, but with dissimulation. (Introduction, p. 18)

The second passage is of interest, as it expresses the idea that interjections do not have truth-conditional meaning.

\section{The Formation of Interjections}

Many works on IALs do not state the source(s) for or method of creation of their interjections, which is not surprising given the small amount of attention paid to interjections and the fact that etymological information in general is often lacking in such works. However, with respect to a fair number of IALs one can find explanations about the formation or choice of their interjections.

\subsection{Interjection-Deriving Suffixes}

Many interjections of IALs are underived. However, a few IALs have an affix for deriving interjections from words of other parts of speech, something which, to my knowledge, is not found in any natural languages. Sprague (1888: 35) says the following about

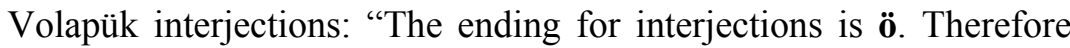

the same practice for other quotations from it. 
verbs in the imperativ [sic] simply drop d, and omit [the] personal ending."9 This might give the impression that interjections (if they are derived) can only be derived from verbs. He then gives the following examples: Spidö! 'Make haste,' Stopö! 'Halt,' and Bafö! 'Bravo!' (the last of these is apparently derived from the verbal root baf- 'be honest, gallant, brave') (ibid.). However, Post (1890: 10) says that interjections "[m]ay be formed from any root by suffixing $\ddot{\mathbf{o}}$ !," that is, $\ddot{o}$ is not limited to verbal roots. The examples he gives are liedö! 'alas!' from lied 'sorrow' and spidö 'hurry up!' from spid 'speed.' 10 Lott (1888: 68) agrees with Post about the freedom that $-\ddot{o}$ has with respect to word classes: "Außer den gebräuchlichen Ausrufwörtern kann jedes Wort durch Anhängung des Vokales ö zu einem Empfindungsworte werden" ('In addition to the usual interjections, any word can become an interjection by attachment of the vowel $\ddot{o}$ '). ${ }^{11}$

Veltparl also has an interjection-deriving suffix, which is not a

9 It would have been simpler to state that interjections can be derived from infinitives by removing the infinitive suffix (-ön) and adding $-\ddot{o}$, or indeed just by removing the $-n$ from the infinitive. Of course these instructions would not work for words other than nouns, but one could say that $-\ddot{o}$ is just added to roots to form interjections. There are underived interjections in Volapük, e.g., $o$ ! 'o!; oh!,' yi! 'avaunt!, begone!, away!,' and yu! 'help!,' although Schleyer (1884: 76) "würden . . . vorschlagen" ('would propose') - $о$ as a suffix for "aller Ausrufwörter" ('all interjections').

10 Thus according to Post spidö is derived from a noun, while Sprague gives the impression that it is derived from a verb. In practice this may not make any difference.

11 Note that Post speaks of roots, while Lott speaks of words. Neither may be completely correct: on the one hand I would not think that $-\ddot{o}$ can be suffixed to any word (e.g., to some finite verb form), but it does not seem to be limited to roots, as Schleyer (1884: 76) gives some examples of interjections built from stems containing the passive prefix ( $p a-$ ), e.g., patakedö! (cf. the infinitive form takedön 'to rest, repose'), which in Schleyer (1885: 68) is glossed as 'quiet!, hush!, st!.' Schleyer (1884: 76) indicates that the active equivalents can also be used, e.g., takedö (for which the gloss in Schleyer (1885: 68) is 'st!, hush!, quiet!, still!,' i.e., it seems to have the same meaning as patakedö). 
82 A Survey of Interjections in International Auxiliary Languages

surprise since it is based on Volapük. This suffix is usually realized as -oe, which on its own is an interjection (which von Arnim (1896: 32) glosses (in German) as 'o!, oho!'), e.g., juvoe! 'help!,' from the noun juv 'help.' It is realized as $-e$ when it is attached to a "Kleinwort" ('small word') which is vowel final, e.g., cie! here!, from $\mathrm{ci}$ 'here.' Among the underived interjections of Veltpart are fi! 'fie!' and stu! 'well I never!.'

Section 27 of Searight's (1935) book on his language Sona is entitled "Interjection." It begins as follows (p. 52):

Exclamations, Vocatives, and Imperatives may be formed by -ha 'name' . . . ; e.g., baha bang! joha O God! ruha go!

The following are the more common exclamations. When required polite $o$ or $-h a$ may be added.

Two things here are unclear. First, what is the difference between exclamations and interjections, if any? Since the section has the title "Interjections" and it mentions "Exclamations, Vocatives, and Imperatives," one might think that these are all kinds of interjections in Searight's view. Second, is -ha required to derive interjections (or can they be zero-derived), given that the last sentence quoted above contains the words "may be added," and for that matter the first sentence says "may be formed by"? There certainly are Sona "exclamations" which do not contain - $h a$, e.g., zeba 'damn' and jukiri 'good morning.' The latter of these appears to be a derived word, from $j u$ 'delight; happy; toy; glad' and kiri 'morning,' which indicates that one can derive interjections, or at least "exclamations," without -ha. Perhaps it is necessary for certain kinds of exclamations. Adding to the confusion is the fact that in Searight's (ibid.: 52-53) list of exclamations is $b a$ 'bang'; is there a difference between it and baha! 'bang!,' and if so, what is it? 


\subsection{Zero-Derived Interjections}

Descriptions of some IALs state that words of other parts of speech can function as interjections. If we look at this situation from another point of view, we could say that such languages allow zero-derivation of interjections from non-interjections.

In his book on Esperanto, Baker (1907: 61) says, "Following is a list of Esperanto words, some of which are always interjections, others frequently used as such." That is, it is possible to use some words which are not basically interjections as interjections. Another source on Esperanto, Kellerman (1910: 216), states, "Verbs in the imperative, and adverbs, are frequently used as interjections, as Atentu! Look out! Aŭskultu! Hark! Benvenu! Welcome!." I find a problem here; how can one distinguish between imperatives which are verbs, and those which are "used as interjections"? For example, when (if ever) would atentu not be an interjection?

Cárdenas (1923: I: 145-6) gives "[t]he main Hom-idyomo interjections," and then states, "It is impossible to give a complete list of interjections, as there are many words which occasionally can perform that function. . . . In practice, however, the use of such words as interjections will not cause any trouble." I would think that the kind of trouble which he has in mind is uncertainty over whether a word is to be taken as an interjection or as its original part of speech. Concerning his language Qôsmianî, Beatty (1922: 37) says, "The common interjections end in $-c$, but a word of any part of speech may be used as an interjection or exclamation." Thus this IAL allows considerable (or complete) freedom with respect to zero-derivation of interjections.

In Idiom Neutral there is also zero-derivation of interjections; Holmes (1903: 20) lists the "primitive interjections" of the language, and then says (ibid.), "The remaining interjections are rendered by other parts of speech," and gives "[t]he principal ones" of these (most of them are morphologically complex, and I 
84 A Survey of Interjections in International Auxiliary Languages

have followed Holmes in indicating the affixes which they contain, although in a different manner than he did):

(2) a re-vis-ad! 'until we meet again!,' audi-a! 'hear!, hello!,' brav-e 'bravo!, good!,' damn-os! 'it is a pity!, what a pity!,' hast-e! 'hurry! be quick!,' o Deo! 'for God's sake!,' parat! 'ready!,' pardon! 'I beg your pardon!,' regret-e! 'alas!, unfortunately!,' silensi! 'silence!, hush!,' sukurs! 'help!,' ve a mi! 'woe to me!'

The $-e$ which occurs in some of these words is presumably the same form as the $-e$ which marks derived adverbs in Idiom Neutral. The -os in damnos seems to be the adjectival suffix -os which "indicate[s] a fullness or multitude of anything" (ibid.: 5), as in petros 'stony,', 12 and the -ad in a revisad is apparently the suffix - $a d$ about which Holmes (ibid.: 25) says the following: "this suffix has no fixed meaning and forms substantives having some reference to the root; it is also used for the formation of substantives that denote the result of an action." Examples of words containing it are edad 'food' and pensad 'thought.' The primitive interjections of Idiom Neutral, as given in Holmes (ibid.: 20) are:

(3) a! 'ah!,' apo! 'away!, begone!,' ekse! 'behold!, look!, here!, there!,' fi! 'fie!,' o! 'O!, oh!,' stop! 'stop!, halt!,' ve! 'woe!'

It is not clear whether stop should be described as "primitive" since there is a verb in the language stopar 'to stop' (i.e., 'to halt'), ${ }^{13}$ though could imagine that both this verb and the interjection stop were borrowed from English independently of each other.

12 The noun damn means 'hurt, harm, damage, detriment.'

13 The $-a r$ at the end of this word is "[t]he general infinitive suffix" (ibid.: 13). 


\subsection{Interjections as Part of a Systematic Scheme of Parts of Speech}

Some IALs, including Esperanto, have suffixes to mark words of different parts of speech. For example, in the case of Esperanto, $-o$ is the ending for nouns, while $-a$ is the adjectival ending. However, most such schemes of suffixes do not extend to all parts of speech; in general the "minor" classes, including interjections, do not have such suffixes. Thus while there are certainly interjections in Esperanto, one cannot tell that a word is an interjection simply by its form.

However, there are a few IALs which have suffixes of this type for interjections. Note that such a suffix is not (necessarily) the same thing as a suffix which derives interjections, discussed in section 3.1 above. There could be a suffix deriving interjections in an IAL without part of speech-marking suffixes, just as in English there is a suffix deriving adverbs (-ly), even though English, like natural languages in general, does not have suffixes marking nouns, adjectives, and so on. In Veltparl, not all interjections bear the interjection-deriving suffix, as there are underived interjections, while in a language with an interjection-marking suffix one might expect all interjections, derived or underived, to contain that suffix.

One such language is Parla; while adjectives and adverbs are marked by $-o$, prepositions by $-n$, and conjunctions by $-t$, interjections end with $-h .{ }^{14}$ The marking of interjections in Dilpok is more complex: it also involves $h$, but either at the beginning or the end of the word. Marchand (1905?: 26) says:

14 We thus see that all the "minor" classes have a marking suffix in this language. One could imagine that there are languages which mark prepositions and perhaps conjunctions with a suffix, but not interjections; there might be a sort of implicational hierarchy of part of speech marking, and if so, I would expect interjections to be at the lower end of it. 
86 A Survey of Interjections in International Auxiliary Languages

Les interjections, servant à exprimer les aspirations et les mouvements exclamatifs de l'âme, seront caractérisées par l'aspirée h, initiale ou finale. Cette lettre n'a pas d'autre emploi.

Ex.: ah! bah! eh! etc., halo! allons! hua! ouais! etc.

('Interjections, which serve to express the aspirations and the exclamatory movements of the soul, will be characterized by the aspirated $h$, (word-)initially or (word-)finally. This letter has no other uses.

E.g.: ah! bah! eh! etc., halo! 'come on!' hua! 'yeah!' etc.')

According to Stadelmann (1945), "English . . . provided the base for Voldu," so Voldu is an a posteriori language, and one drawing largely on a single language. One might therefore be surprised to see the following statement about interjections (p. 27): "They are mostly characterized by an $h$ or a double vowel," as it sounds like the kind of statement one would find about an a priori language. However, this property of (the majority of) interjections may well be a coincidence, rather than a planned feature, as at least some of the example interjections which Stadelmann then gives (ibid.) seem to have come from English: ah! 'alas,' uh! (fear, disgust), ha! (laughter), ho! 'halo' (calling), ahá! (confirmation), aa! (surprise), o! 'oh!.'

Latinulus is based on Latin, but even so, most interjections have a "characteristic" ending: Martellotta (1919: 25) says, "Tutte le interiezioni, eccetto 1 ' $o$ ! terminano in $n$ che è la loro caratteristica" ('All the interjections except $o$ ! end in $n$, which is their characteristic feature.'). The two examples which he (ibid.) gives are vion! 'viva!' ('long live!') and báfon 'abbasso!' ('down with!'). 15

15 On page III Martellotta states, "Gli avverbi, le preposizioni, le congiunzioni e le interiezioni sono state semplificate ed a ciascuna classe è stata assegnata una 
There is another way of clearly marking different parts of speech, with different patterns of consonants and vowels, or with structures differing in other ways. This strategy is used in Eichhorn's Weltsprache (another Latin-derived IAL): interjections consist of three syllables, unlike conjunctions, which consist of one syllable, and prepositions and adverbs, which are two syllables long. Most adjectives are also made up of three syllables, but perhaps Eichhorn thought that there would be little chance of confusing them with interjections. Although Eichhorn's language is an a posteriori language, it has some apparently a priori interjections, e.g., alila to express joy.

In the a priori language Babm interjections have a particular form (with some variation); Okamoto (1962: 5-6) says, "An exclamation consists of two long-sound letters, and $w$ may be added to the middle or end. Any long-sound letter is accented according to the need of feeling." The examples he then gives are $a o$, awe, owi, and $u u$ for praise, dearness, surprise, and sorrow respectively. ${ }^{16}$

There may be a further form-meaning/function connection: in some a priori languages words of similar meaning are similar in form, beyond simple formal distinctions among parts of speech (by suffix or structure), and this is true of Babm. For example, nouns denoting insects contain the letters $\left\langle\right.$ b $>$ and $<_{\mathrm{v}}>$ or $\left\langle\right.$ b $>$ and $<_{\mathrm{w}}>$ (not necessarily adjacent), as in bavf 'dragonfly' and bvoj 'honeybee,' while words for weapons and other things related to

desinenza speciale" ('The adverbs, the prepositions, the conjunctions, and the interjections have been simplified and to each class a special ending has been assigned.'). It is interesting that Martellotta felt it necessary to simplify the interjections, since they (or at least the most typical of them) generally are not complex words.

16 Although Babm uses the Roman alphabet, it uses it as a syllabary; for example, the letter $<\mathrm{m}>$ stands for the syllable [mu]. The vowel letters are "long-sound letters," as the vowel in the syllable which they stand for is long (and the syllable in fact is only a long vowel), e.g., $<\mathrm{i}>$ is pronounced [i:]. 
military activities contain $<\mathrm{h}>$ and $<\mathrm{q}>$, as in hiqd 'short sword' and hqap 'barracks.' Okamoto (1962) gives far fewer words for "exclamations" than for nouns or verbs, and he does not classify them into labelled groups based on their meaning as he does for those parts of speech, but consider the entire list of exclamations, given below:

Table 1. Babm Exclamations (Okamoto 1962: 143)

\begin{tabular}{|l|}
\hline$a a$ for admiration \\
\hline$a i$ for deep impression \\
\hline$a o$ for praise \\
\hline$a w e$ for dearness \\
\hline$e e$ for listening \\
\hline eo for listening in the meaning of acceptance \\
\hline ewo 'lo!' \\
\hline$i i$ for disappointment \\
\hline$i o$ 'hullo!' \\
\hline$o a$ for approval \\
\hline$o u$ for astonishment \\
\hline$o w i$ for surprise \\
\hline$o w o$ for fear \\
\hline$u a$ for regret \\
\hline$u e$ for dissatisfaction \\
\hline$u i$ for resistance (opposition) \\
\hline$u u$ for sorrow \\
\hline
\end{tabular}

It is not clear whether any sound-meaning connection is intentional (Okamoto may simply have listed the interjections as he thought of them), but to some extent interjections that have similar meanings are similar with respect to the letters (i.e., syllables) they contain. All those which begin with $u$ express negative emotions, although not all interjections expressing 
negative emotions being with $u$, the exceptions being $i i$ and owo. It is difficult to make any generalization about interjections starting with $i$ (especially since it is not clear exactly what "hullo!' is supposed to mean). Most or all of the interjections beginning with $a$ (depending on what "deep impression" means) represent positive feelings. Two out of the three interjections whose first component is $e$ involving "listening," while the two interjections expressing some degree of surprise both start with $o$ (but the two other interjections which begin with $o$ have unrelated meanings). There is thus a partial correlation between form and meaning among the Babm interjections.

The underived interjections of Sotos Ochando's Lengua Universal, another a priori language, also have a characteristic form (again with a small degree of variation), as they all have the same final segment, $f$. Below are "las interjecciones mas comunes y usuales" ('the most common and usual interjections'; Sotos Ochando 1886: 140) of this language. 
Table 2. Interjections of Sotos Ochando's Lengua Universal (Sotos Ochando 1886: 140)

\begin{tabular}{|c|c|}
\hline Af & Qué pena, qué dolor! ('What a pity, how sad!')17 \\
\hline Aef & Qué pesar, qué arrepentimiento! ('What sorrow, how regretful!') \\
\hline Aif & ¡Qué desgracia, qué fatalidad! ('What misfortune, what bad luck!') \\
\hline Aof & ¡Qué lastima, qué compasíon! [sic] ('What a pity, what a pity!') \\
\hline Auf & ¡Qué miedo, qué espanto! ('How frightening, how awful!') \\
\hline$E f$ & ¡Qué ira, qué indignacion! ('How angry I am, what an outr \\
\hline Eaf & ¡Qué ódio, qué aversion! ('How hateful, how distasteful!') \\
\hline Eif & ¡Qué insulto, qué ultraje! ('What an insult, what an outrag \\
\hline Eof & ¡Qué desprecio, qué burla! ('What contempt, what a moc \\
\hline If & ¡Qué placer, qué alegría! ('What a pleasure, how wond \\
\hline Iaf & ad! ('What a delight, what hap \\
\hline Ief & ¡Qué fortuna, qué suerte! ('What good fortune, what good \\
\hline$O f$ & $\begin{array}{l}\text { Esclamacion é invocacion: ¡Dios mio! ('Exclamation and invocation: } \\
\text { my God!') }\end{array}$ \\
\hline Oaf & ¡Atencion, escuchad! ('At \\
\hline Oef & Escitacion: ea, alerta! ('Excitation: Come on, \\
\hline Oif & ¡Alto, silencio, chito! ('Stop, silence, hush!') \\
\hline$U f$ & ta allá! ('(Get) out, go away!') \\
\hline Uaf & ¡Qué asco, qué por \\
\hline Uef & frenta! ('What a disgrace, \\
\hline
\end{tabular}

Again, there may be a partial further form-meaning connection. It is interesting that the majority of these interjections express negative feelings. The few that express positive emotions begin with $i$, but this may not be the result of a planned scheme.

\subsection{Sources of $\boldsymbol{A}$ Posteriori Interjections}

Detailed etymological information is lacking in most

${ }^{17}$ Note that that spelling and the use of accents in this source is somewhat different from contemporary Spanish. 
descriptions of IALs, so in many cases it is difficult to tell with certainty what the source of an a posteriori interjection (or other word) is. In this section, I will discuss the etymology of interjections in a few IALs.

In some a priori languages, as we have seen, the interjections were (not surprisingly) formed in an a priori manner. However, this is not true of other types of IALs and does not even seem to be true of all a priori IALs. Edmonds' Philosophic Language follows the same sort of vocabulary scheme as e.g., Babm, i.e., with words with similar meanings being similar in form, e.g., the words for 'gold,' 'silver,' and 'tin' are pu'nzoo, fu'nzoo, and tu'nzoo respectively. However, unlike Babm, at least some of the interjections seem to be a posteriori, as can be seen from the following table, which contains the interjections given in Edmonds (1856?: Introduction: 18-19). In the second column English interjections, or phrases containing them, appear first, followed by interjections of the Philosophic Language. Edmonds distinguishes between the first eight types of interjection and the last six (I have indicated this with a thick line in the table); he says, "The preceding [i.e., types 1-8] are not necessarily addressed to any other person: expressing only what passes in the breast of the speaker. The following [types 9-13] are more social, being designed to affect the party addressed" (ibid.: 19). 
92 A Survey of Interjections in International Auxiliary Languages

Table 3. Some Interjections of Edmonds' Philosophic Language

\begin{tabular}{|c|c|c|}
\hline 1 & $\begin{array}{l}\text { Expressing } \\
\text { admiration }\end{array}$ & $\begin{array}{l}\text { Heigh Sirs! How beautiful! What a beauty! } \\
\text { Philosophic: Hai! Jyoo'tu! Sloo!18 }\end{array}$ \\
\hline 2 & $\begin{array}{l}\text { Doubt, hesitation, } \\
\text { and private } \\
\text { reasoning }\end{array}$ & $\begin{array}{l}\text { Hm! pronounced hum, with the lips closed; the } \\
\text { sound passing out at the nose. Philosophic: the } \\
\text { same sound }\end{array}$ \\
\hline 3 & Contempt & $\begin{array}{l}\text { Pish! Tysh! Tush! Bah! Philosophic: Pis ! Tis! } \\
\text { Tus } !^{19} \text { Bha! }\end{array}$ \\
\hline 4 & Laughter & Ha! ah! ah! Philosophic: Ha-! ha! ha! \\
\hline 5 & Sorrow & $\begin{array}{l}\text { Oh dear! Oh! Alas! Lack a day! Ah! } \\
\text { Philosophic: Ho! Ula's! Ula'k! }\end{array}$ \\
\hline 6 & Hatred & $\begin{array}{l}\text { Vau! Hau! Avaunt! Philosophic: the same } \\
\text { sounds }\end{array}$ \\
\hline 7 & Wishing, desire & $\begin{array}{l}\text { Oh that! Oh for! o si! } \text { (See the Optatives, } \\
\text { page } 109 \text { [of Book I] })^{20}\end{array}$ \\
\hline 8 & $\begin{array}{l}\text { Disgust or } \\
\text { shame }\end{array}$ & Fie! fie! Philosophic: Fị! fị! \\
\hline 9 & Vocative & $\begin{array}{l}\text { O: as, O my friend! Soho there! Holloa! } \\
\text { Philosophic: Ho! Soho! Hollo! }\end{array}$ \\
\hline 10 & Imperative & $\begin{array}{l}\text { Hush! Ish! St! i.e., Be silent! Philosophic: } \\
\text { Hus! Is! St! }\end{array}$ \\
\hline 11 & $\begin{array}{l}\text { Bespeaking } \\
\text { attention }\end{array}$ & Oh: as, Oh Sir! Philosophic: Ho! \\
\hline 12 & $\begin{array}{l}\text { Expressing } \\
\text { attention }\end{array}$ & $\begin{array}{l}\text { Well! Ah! Yes! Philosophic: Fo'ndị! Zim! Zil! } \\
\text { Ham! Gel! \&c. }\end{array}$ \\
\hline 13 & $\begin{array}{l}\text { Insinuation or } \\
\text { blandishment }\end{array}$ & $\begin{array}{l}\text { Now, my child! Well, my dear! Now then, } \\
\text { don't fear! Philosophic: Gel! Fo'ndi! }\end{array}$ \\
\hline 14 & Threatening & $\begin{array}{l}\text { Woe! woe! Va victis! Philosophic: Oh } \\
\text { fra'mboo, pemprufoo"ruz! Woe, to the } \\
\text { vanquished! }\end{array}$ \\
\hline
\end{tabular}

18 The Philosophic Language has some non-standard letters. Below are some of Edmonds' (1856?: Book I: 1) English example words for the letters occurring in this table:

$$
\begin{aligned}
& <\underline{\mathrm{a}}>=\text { English }<\mathrm{a}>\text { in art, ask, after } \\
& <\underline{\mathrm{e}}>=\text { English }<\mathrm{e}>\text { in me, we } \\
& <\underline{\mathrm{i}}>=\text { English }<\mathrm{i}>\text { in idle, wife } \\
& <\underline{\mathbf{0}}>=\text { English }<0>\text { in over, gold } \\
& <\underline{\mathrm{s}}>=\text { English }<\mathrm{sh}>\text { in sheet, rash }
\end{aligned}
$$


There are several things that are not clear here. I assume that when part of the English expression is in italics it is only that part which the Philosophic Language expressions are equivalent to. However, looking at the first row of the table, are Hai!, Jyoo'tu!, and Sloo! equivalent to Heigh, How, and What respectively, or can any of the former be used to translate any of the latter? The twelfth row may be even more confusing since there are three English expressions, but five words of the Philosophic Language (followed by "\&c.").

The interjections of the Langue Isly, which is a modified form of Latin, are the same as in Latin. This is also true of Nov Latin, another IAL derived from Latin. Communia, which drew largely on Latin, took its interjections from Latin, and from Greek. It might seem obvious, and not worth stating, that such languages would use Latin interjections, but recall that in Eichhorn's Weltsprache interjections (a few of which may be a priori) are made up of three syllables, and that Latinulus has a suffix marking interjections, meaning that even if these languages borrowed Latin interjections, they would not have the same form as they did in Latin.

\subsection{Other Issues in the Formation of Interjections}

In this section I will mention unusual features relating to interjections in IALs.

$<\underline{\mathrm{t}}>=$ English $<\mathrm{th}>$ in thief, pith

The symbol $\langle>$ is the "accentual mark" (ibid.: 3), which follows "the accented vowel" (ibid.); two of these in succession (i.e., <">) make up the "emphasis"; I do not know what the difference between accent and emphasis is.

${ }^{19}$ In Edmonds' list, there is a comma after Tus, but I assume that this is an error, as there is an exclamation point after the other interjections in the list.

${ }^{20}$ Edmonds (1856?: Book I: 109) states, "The Optative characteristic is 'Ho'kwun' which, like the two English words 'Oh that!' expresses an apparently intense wish, but does not assert it." 
94 A Survey of Interjections in International Auxiliary Languages

The vocabulary of Ruggles' Universal Language is largely based on Latin, but also follows some a priori type systems, and such a system is involved in the interjections, as can be seen from the list below, from Ruggles (1829: 58):

Table 4. Interjections of Ruggles' Universal Language

\begin{tabular}{|l|l|}
\hline \multicolumn{1}{|c|}{ Positive } & \multicolumn{1}{c|}{ Contrative } \\
\hline$h i$, joy, love, delight & $y i$, grief, hatred, anger, displeasure \\
\hline$h e$, desire & $y e$, aversion, disgust \\
\hline$h a$, laughter & $y a$, vexation, chagrin \\
\hline$h o$, reverence & $y o$, contempt, derision \\
\hline$h u$, confidence, hope, encouragement & $y u$, fear, despair, discouragement \\
\hline$h j$, praise, approbation & $y j$, censure, shame! \\
\hline$h c$, prayer, beseeching & $y c$, imprecation, defiance \\
\hline$h q$, tumult, huzza! & $y q$, silence, hush! \\
\hline$h x$, wonder, astonishment & $y x$, indifference, apathy \\
\hline$h z$, invocation, calling to, summonising & $y z$, away, begone \\
\hline & \\
\hline
\end{tabular}

It can be seen that the "positive" interjections begin with $h$-, and the "contrative" ones with $y$-; $y$ - is involved in the formation of negative words of some other parts of speech, e.g., $d y x$ 'therefore not' (cf. $d u x$ 'therefore'), and $h$ - is involved in the formation of positive adjectives (which Ruggles calls "adnouns"), e.g., bonhin 'good' (cf. bonyin 'bad'). This system is something that clearly would not be found in a natural language.

Spelin has a suffix or deriving interjections, -oe. However, it also has a class of word which is related to interjections (or is a type of interjection?): among the various types of pronouns in this language is the "Interjectio pronominalis" (Bauer 1888: 16). Bauer (ibid.) gives the following table of members of this group with their equivalents in several other languages (I have slightly modified the table): 
Table 5. Pronominal Interjections of Spelin

\begin{tabular}{|l|c|c|c|c|c|c|}
\hline & Spelin & German & French & Croatian & Latin & Volapük \\
\hline 1. Interr. & kevoe? & siehewo? & - & - & (siccine?) & - \\
\hline 2. Person. & ivoe! & siehehier! & voici! & evo! & ecce! & eko! \\
\hline & evoe! & siehe da! & voilà! & eto! & - & ekö \\
\hline & avoe! & siehedort! & voilà! & eno! & - & ekü \\
\hline
\end{tabular}

Bauer (ibid.) does not discuss these words, but gives an example of one of them in use:

(4) spevoe! nemikös

'Siehe da! Feinde von überall'

'Look there! Enemies on all sides'

The $s p$ - at the beginning of spevoe is, I believe, a truncated version of spe, the morpheme which means 'all' (as in spelin 'the language of everyone'); thus a more literal translation of (4) would be something like 'Look there everywhere! (There are) enemies.'

\section{Instructions on the Use of Interjections}

As we have seen, some sources on IALs say little or nothing about interjections, although they may give lists of them or have entries for some of them in their dictionaries. The authors of such sources may have thought that it was obvious how to use any interjections in their language, but this is not necessarily so. In some cases, when instructions are given, they are not detailed. For example, Martellotta (1919: 140) says, "Le interiezioni latinule si usano con le stesse norme delle lingue moderne" ("The interjections of Latinulus are used according to the same rules as in modern languages.').

According to Sprague (1888: 4), the "uses" of interjections in 
96 A Survey of Interjections in International Auxiliary Languages

Volapük, and of all the other parts of speech, "are the same as in English." Elsewhere (ibid.: 7), in his discussion of cases, he mentions a function of one interjection:

The kimfal [nominative], preceded by the interjection "o" and followed by an exclamation point, is used in addressing a person: "o söl!" "Sir." This is sometimes considered as a separate case, called the kimofal or vocativ [sic]." ... “o" is sometimes omitted in this case.

Recall that Okamoto (1962: 143) lists 17 Babm "exclamations." The way in which most of them, e.g., $a a$ "for admiration," $i i$ "for disappoinment," and owo "for fear," are to be used is fairly clear in the absence of any instructions, but this is not true of all of them. The ones that I see as possibly problematic from this point of view are $a i$ "for deep impression," ee "for listening," eo "for listening in the sense of acceptance," and io "hullo!." One might wonder whether ee means 'listen!' or 'I am listening to you'; I believe that it means the latter, given the gloss for $e o$, which I interpret as something like 'I am listening to you and agree with you.' In addition, the one Babm sentence in Okamoto (1962) containing ao may make one wonder about its meaning or function:

(5) Ao Poyt cj cy loic V!

'Oh God bless me!' (ibid.: 26) 21

In this sentence, ao seems to be acting as a vocative marker, but according to Okamoto (ibid.: 143) it is used "for praise." Perhaps

21 This sentence is difficult to give a morpheme-by-morpheme gloss of. Poyt and loic mean 'god, deity' and 'bestow a favor, bless' respectively and $V$ is the 1st person singular pronoun. Okamoto (1962: 17) says the following about the other two words in the sentence (besides $a o$ ): "cj makes a polite verb by preceding or suffixing" and "cy makes a supplicatory verb by preceding or suffixing." 
it is a sort of honorific particle/interjection.

In contrast to e.g., Martellotta (1919), Wennergren (2013) gives relatively detailed information on the use(s) of some Esperanto interjections. The passage below (p. 328) is an example of this, about $h a$ 'ah':

Ha montras ekmiron aŭ surprizon: Ha, kiel bele! Ha! kie vi ricevis la tutan monon? Ripeta ha povas esprimi pli vivan senton: "Ha ha!" ekgemis la malgranda Niko, vidante, kiel la tuta manĝajo malaperas. Ripeta ha estas ankaŭ uzata kiel sonimito de ridado: Kiel oni povas ne ridi? [...] $]^{22}$ ha, ha, ha!

$H a$ plus la neoficiala ekkria vorteto $l o$... formas kune la duvortan ekkrion ha lo, kiu estas uzata kiel alvoko, precipe en telefonado.

(' $\mathrm{Ha}$ shows amazement or surprise: Ha, how beautiful! Ha! where did you get all that money? Repeated ha can express a more lively feeling: "Ha ha!" groaned small Nick, seeing how the whole meal disappeared. Repeated $h a$ is also used as an onomatopoeia for laughter: How can one not laugh? [...] ha, ha, ha!

$\mathrm{Ha}$ and the unofficial interjection lo together form the two word interjection ha lo, which is used as a call(ing) [to someone], mainly on the telephone.')

\section{Ideas of IAL Designers and Proponents on the Nature of Interjections}

I will now briefly discussion some ideas about interjections expressed by authors on IALs.

22 This ellipsis is present in the original source. 
In Quiles \& López-Menchero's (2012) A Grammar of Modern Indo-European there is the following statement: "Interjections are natural exclamations of pain, surprise, horror, and so forth, and they are onomatopoeic in nature" (p. 282). This statement seems partly incorrect; although many linguists would place onomatopoeias in the class of interjections, not all interjections are onomatopoeias. This is true, I would think, of some of the Modern Indo-European interjections which they then give, e.g., bha 'truly.'

Olfaa (2011: 12), on Paqatyl, lists interjections among the open word classes. This is interesting because there is disagreement in the literature on natural languages about whether interjections are an open or a closed class, e.g., according to Schachter (1985: 23) they are closed, while Drescher (1997: 242) asserts that they are open, and Cuenca (2000: 36) states that they are "semi-open." Jovanović (2004: 19-20), in a paper on English interjections, says:

It is not very easy to judge whether interjections are an open or a closed set of words, since they form a relatively stable group of easily identifiable words and phrases with particular communicative function. Interjections of English make up a set of over 500 words or one-word utterances speakers use on various occasions. However, it is not difficult to imagine new interjections complementing the existing contingent, as opposed to, let's say, pronouns.

One's answer to this question may depend on what items one includes in the set of interjections, and this is something that there is also disagreement on.

In his book on Neoslavonic Merunka (2014: 103) includes quotations among interjections:

An interjection or an exclamation is a non-inflected word used to express an emotion or sentiment on the part of 
the speaker. ... Moreover, any direct speech closed in quotation marks is semantically considered as an interjection too.

example:

“Dobro jesme!” je kazal tamtoj člověk.

"We are all right" said that man.

\section{“Žaba "plesk!" je skočila do vody.}

A frog "splash!" jumped into the water.

This seems to be an odd point of view indeed. Possibly the second example (which does not actually involve a quotation) gives a clue as to the thinking behind it. Some authors, e.g., Cuenca (2000: 34), consider onomatopoeias to be interjections, and a direct quotation is like an onomatopoeia in that it represents phonetically a sound, or rather a series of sounds (i.e., one or more words), which has occurred.

\section{Conclusions}

We have seen some quite different ways of creating interjections and some different views on them (as well as differing amounts of space devoted to them). Some of the former (e.g., the use of affixes to derive interjections, or to mark them as such) seem unusual from the point of view of natural languages, while the use of zero-derivation occurs both in IALs and in many natural languages. Designers of IALs might be advised to give more attention to interjections, as this class of words may not be as unimportant or as simple as many authors suppose. 
100 A Survey of Interjections in International Auxiliary Languages

\section{References}

Alfandari, A. 1961. Cours Pratique de Neo. Brussels: Editions Brepols.

Baker, A. (comp. \& ed.) 1907. The American Esperanto Book.

Girard, KS: Appeal to Reason.

Bauer, G. 1888. Spelin. Brussels: C. Mouquardt.

Beatty, W. 1922. Qôsmianî. Washington, DC: The Fraternity Press.

Beermann, E. 1907. Novilatin. Leipzig: Dieterich'sche Verlagsbuchhandlung Theodor Weicher.

Butler, M. 1965. Step by Step in Esperanto ( $8^{\text {th }}$ edition). Orela: The Esperanto Publishing Company.

Cárdenas, C. 1923. Hom-Idyomo ( $2^{\text {nd }}$ edition). Leipzig: Fischer \& Wittig.

Cuenca, M. 2000. Defining the Indefinable? Interjections. Syntaxis 3, 29-44.

de Saussure, R. (under the name Antido). 1919. Fundamento de la internacia lingvo Esperantida (Revised and approved by the Esperantida Academy). Bern: Esperantida Akademio.

Drescher, M. 1997. French Interjections and their Use in Discourse. In S. Niemeier \& R. Dirven (eds.), The Language of Emotions 233-246. Amsterdam: John Benjamins.

Edmonds, G. 1856?. A Universal Alphabet, Grammar, and Language. London: Richard Griffin \& Company.

Fetcey, S. \& le Comité Linguistique Kotava. 2013. Kotava: grammaire officielle complète (version III.14). Available at URL $<$ http://www.kotava.org/fr/fr_pulviropa_000.pdf $>$.

Giles, A. 2014. The Algilez Grammar. Available at URL $<$ http://www.algilez.com/1ALG2/files/assets/common/download s_35c3309c/publication.pdf $>$.

Gisbert, D. \& D. Lorrio. 1862. Manual de lengua universal.

Madrid: Imprentade J. Martin Alegría. 
Gode, A. \& H. Blair. 1951. Interlingua. New York: Storm Publishers.

Goffman. E. 1981. Forms of Talk. Philadelphia, PA: University of Pennsylvania Press.

Holmes, M. 1903. Diksionar de Idiom Neutral / Dictionary of the Neutral Language. Rochester, NY: John P. Smith Printing Company.

Jovanović, V. 2004. The Form, Position, and Meaning of Interjections in English. Linguistics and Literature 3.1, 17-28. Kellerman, I. 1910. A Complete Grammar of Esperanto. New York: D. C. Heath \& Company.

Kennedy, B. 1879. The Public School Latin Grammar (5 $5^{\text {th }}$ edition). London: Longmans, Green, \& Co.

Lott, J. 1888. Die Kunst, die internationale Verkehrssprache "Volapük" schnell zu erlernen. Vienna: A. Hartleben's Verlag.

Marchand, A. 1905?. Le dilpok en six leçons. Besançon: Imprimerie Jacquin.

Martellotta, V. 1919. Latinulus. Bari: Stab. Tip. F. Casini \& Figlio.

Merunka, V. 2014. Neoslavonic Zonal Constructed Language. České Budějovice: Nová Forma.

Monnerot-Dumaine, M. 1960. Précis d'interlinguistique générale et spéciale. Paris: Librarie Maloine.

Nate, R. 1996. The Interjection as a Grammatical Category in John Wilkins' Philosophical Language. Historiographia Linguistica 23.1-2, 89-109.

O’Connor, C. 1917. American. Buffalo: Hausauer-Jones Printing Co.

Okamoto, F. 1962. Universal Auxiliary Language Babm. Tokyo: self-published.

Olfaa, K. 2011. Paqatylet Ukisu Antskolai (6 ${ }^{\text {th }}$ edition). Recife: WorldLang Editions. Available at URL $<$ http://dl.dropboxuserc ontent.com/u/19369461/PAQGRAM.pdf>. 
102 A Survey of Interjections in International Auxiliary Languages

Post, A. 1890. Comprehensive Volapük Grammar. Boston: Carl H. Heintzemann.

Quiles, C. \& F. López-Menchero. 2012. A Grammar of Modern Indo-European $\left(3^{\text {rd }}\right.$ edition). Badajoz: Indo-European Language Association. Available at URL $<$ http://indo-europea n.info/a-grammar-of-modern-indo-european-third-edition.pdf $>$.

Ruggles, J. 1829. A Universal Language. Cincinnati: M'Calla \& Davis.

Schachter, P. 1985. Parts-of-Speech Systems. In T. Shopen (ed.), Language Typology and Syntactic Description Volume I 3-61. Cambridge: Cambridge University Press.

Schleyer, J. 1884. Volapük (Weltsprache): Grammatik der Universalsprache für alle gebildete Erdbewohner ( $3^{\text {rd }}$ edition). Überlingen am Bodensee: die Buchdruckerei von August Feyel und die Buchhandlung von Aug. Schoy. . 1885. Grammar of Volapük: The Language of the World. Translated by W. Seret. Glasgow: Thomas Muarry \& Son. Searight, K. 1935. Sona. London: Kegan Paul, Trench, Trubner \& Co.

Sotos Ochando, B. 1886. Diccionario de lengua universal $\left(2^{\text {nd }}\right.$ edition). Buenos Aires: Taller Tipográfico de la Penitenciaría. Sprague, C. 1888. Hand-Book of Volapük. New York: The Office Company.

Stadelmann, J. 1945. Voldu Textbook. Caracas: Lit. yTip. Vargas. Stempfl, J. 1889. Myrana und Welt-Sprache. Kempten: Verlag der Jos. Kösel'schen Buchhandlung.

Talmey, M. 1925. Arulo. New York: Ilo Press. von Arnim, W. 1896. Lehrbuch einer internationalen Verkehrs-Sprache genannt "Veltparl" ( $2^{\text {nd }}$ edition). Erfurt: Verlag von Eduard Moos.

Weferling, E. 1974. Standard-Gramatika del International Auksiliari Lingue $\left(6^{\text {th }}\right.$ improved edition). Braunschweig: self-published.

Weisbart, J. 1912. Europal. Berlin: Michaelis \& Neumann. 
Wennergren, B. 2013. Plena Manlibro de Esperanta Gramatiko. Available at URL < http://bertilow.com/pmeg/elshutebla/PMEG _ 15.0_provizora_PDF_17_Junio_2013.pdf $>$.

Wilkins, J. 1668. An Essay towards a Real Character, and a Philosophical Language. London: S. Gellibrand \& J. Martyn. Young, R. 2007. An English Pocket Guide to Interlingua. Available at URL < http://www.prism.gatech.edu/ ir12/books/a n-english-pocket-guide-to-interlingua.pdf $>$. 